\title{
MINAT BELI ULANG BERBASIS CITRA MEREK, HARGA, DAN KUALITAS PRODUK (KASUS PADA SATE MARANGGI SN4444 TAJUR BOGOR)
}

\section{RE- PURCHASE INTEREST BASED ON BRAND IMAGE, PRICE, AND PRODUCT QUALITY (CASE ON SATE MARANGGI SN4444 TAJUR BOGOR)}

\author{
Sudarijati ${ }^{1)}$; Titiek Tjahja Andari ${ }^{2)}$; Rizka Rosyada ${ }^{3)}$ \\ ${ }^{1)}$ Universitas Djuanda; ${ }^{2)}$ Universitas Djuanda; ${ }^{3)}$ Universitas Djuanda \\ Correspondence Author: sudarijati@unida.ac.id
}

\begin{abstract}
This study aims to see how consumers respond to brand image, price, product quality and repurchase interest in Sate Maranggi SN4444 Tajur, Bogor City. In addition, another objective is to see the relationship between brand image, price, and product quality jointly and individually on repurchase interest. The object and location of this research are the consumers of Sate Maranggi SN4444 in Tajur, Bogor City. The research method used is descriptive, verification and multiple linear regression analysis. The sample in this study was 100 consumers who had made purchases more than twice. The average result of consumer responses to brand image is said to be very good, the price is said to be very appropriate, the quality of the product is said to be very good and the interest in repurchasing is said to be very high. The result of the correlation coefficient shows that the $R$ value is 0.710 , which has a strong correlation. The coefficient of determination shows an $R$ square value of 0.504, which means that the contribution of the influence of the independent variable on the dependent variable is $50.4 \%$. While the remaining $49.6 \%$ is influenced by other factors. Based on the research results, simultaneously and partially brand image, price, and product quality have a positive and significant effect on repurchase interest.
\end{abstract}

Keywords: Brand Image, Price, Product Quality, and Repurchase Interest.

\section{ABSTRAK}

Penelitian ini mempunyai tujuan untuk melihat bagaimana tanggapan konsumen terhadap citra merek, harga, kualitas produk dan minat beli ulang pada Sate Maranggi SN4444 Tajur Kota Bogor. Selain itu, tujuan lain adalah untuk melihat hubungan citra merek, harga, dan kualitas produk secara bersama-sama maupun individual pada minat beli ulang. Objek dan lokasi penelitian ini yaitu konsumen Sate Maranggi SN4444 di Tajur Kota Bogor. Metode penelitian dengan metode deskriptif, verifikatif dan analisis regresi linear berganda. Sampel dalam penelitian ini sejumlah 100 konsumen yang telah melakukan pembelian lebih dari dua kali. Hasil rata-rata tanggapan konsumen pada citra merek dikatakan sangat baik, harga dikatakan sangat sesuai, kualitas produk dikatakan sangat baik dan minat beli ulang dikatakan sangat tinggi. Hasil koefisien korelasi menunjukkan nilai R sebesar 0,710, memiliki korelasi yang kuat. Hasil koefisien determinasi menunjukkan nilai Rsquare sebesar 0,504 yang berarti besaran kontribusi pengaruh variabel independen terhadap variabel dependen sebesar 50,4\%. Sedangkan sisanya 49,6\% dipengaruhi oleh faktor lain. Berdasarkan hasil penelitian, secara simultan dan parsial citra merek, harga, dan kualitas produk mempunyai pengaruh yang positif serta signifikan terhadap minat beli ulang.

Kata Kunci: Citra Merek, Harga, Kualitas Produk, dan Minat Beli Ulang 


\section{PENDAHULUAN}

Persaingan industri pangan di Indonesia saat ini menjanjikan suatu peluang dan tantangan. Banyak sekali wirausahawan yang melihat peluang bisnis kuliner sebagai peluang yang menjanjikan keuntungan. Banyak perusahaan berlomba-lomba untuk mendapatkan ketertarikan konsumen dari pesaing dengan maksud agar mampu mempertahankan citra perusahaan. Bagi sebagian bisnis yang belum mampu menaklukkan tantangan zaman, maka bisnis tersebut akan tersingkir. Meskipun bisnis kuliner telah banyak, sektor ini tetap memiliki peluang untuk dijalankan. Dalam berbisnis di bidang kuliner diperlukan strategi yang tepat agar mampu bersaing dengan yang lain. Para pengusaha bisnis kuliner harus mampu melihat peluang-peluang yang ada serta meningkatkan kreatifitas dalam menawarkan produk terbaiknya.

Menu kuliner yang diminati konsumen berbeda-beda, ada yang menyukai menu tradisional ataupun menu modern. Sekarang banyak sekali menu-menu moderen yang ditawarkan kepada konsumen, namun menu tradisional tidak kalah menarik juga. Menumenu tradisional ini patut dikembangkan. Banyak orang dari berbagai kalangan yang mengatakan bahwa menu-menu tradisional akan memenangkan tempat di hati para penikmat makanan di Indonesia. Karena sekarang ini banyak sekali orang-orang yang merasa jenuh dengan penawaran menu-menu moderen sehingga lebih memilih menu-menu tradisonal. Pengaruh perkembangan zaman membuat banyak produk barang ataupun jasa yang memberikan berbagai macam kelebihan maupun keunikan dari masing-masing produknya. Sehingga para konsumen memiliki berbagai macam alternatif pilihan dalam mempergunakan produk barang ataupun jasa yang diberikan oleh produsen.

Upaya yang dilakukan dalam menjaga keberlangsungan setiap usaha tentunya tidak mudah. Sate Maranggi SN4444 harus mempertahankan citra merek, harga, dan kualitas produknya agar konsumen melakukan pembelian berulang. Sate Maranggi SN4444 memperoleh pendapatan yang berfluktuasi disetiap bulannya pada tahun 2018. Berikut data pendapatan Sate Maranggi SN4444 pada tahun 2018:

Tabel 1 Jumlah Pendapatan Sate Maranggi SN4444 Tahun 2018

\begin{tabular}{lll}
\hline Bulan & Jumlah Pendapatan (Rp) & Perubahan(\%) \\
\hline Januari & $197.000 .000,-$ & - \\
Februari & $202.000 .000,-$ & 2,47 \\
Maret & $207.000 .000,-$ & 2,41 \\
April & $209.000 .000,-$ & 0,95 \\
Mei & $221.000 .000,-$ & 5,42 \\
Juni & $228.000 .000,-$ & 3,07 \\
Juli & $206.000 .000,-$ & $(10,67)$ \\
Agustus & $185.000 .000,-$ & $(11,35)$ \\
September & $177.000 .000,-$ & $(4,52)$ \\
Oktober & $195.000 .000,-$ & 9,23 \\
November & $227.000 .000,-$ & 14,09 \\
Desember & $230.000 .000,-$ & 1,30 \\
\hline Jumlah & $\mathbf{2 . 4 8 4 . 0 0 0 . 0 0 0 , -}$ & - \\
\hline Rata-rata & $\mathbf{2 0 7 . 0 0 0 . 0 0 0 , -}$ & $\mathbf{1 , 1 3}$ \\
\hline
\end{tabular}

Sumber: Sate Maranggi SN4444, 2019 
Berdasarkan Tabel 1 tersebut pendapatan Sate Maranggi SN4444 pada beberapa bulan mengalami penurunan yaitu pada bulan Juli, Agustus, dan September. Pada tahun 2018, pendapatan tidak meningkat secara signifikan. Rata-rata peningkatan sejak Januari sampai dengan Desember 2018 hanya sebesar $1,13 \%$. Hal tersebut belum mencapai angka dari target perusahaan yang menetapkan rata-rata kenaikan pendapatan setiap tahunnya yaitu sebesar $2,5 \%$. Berdasarkan wawancara yang telah dilakukan dengan beberapa konsumen di Sate Maranggi SN4444 bahwa rata-rata konsumen mengatakan bahwa citra merek Sate Maranggi SN4444 belum diketahui ataupun dikenal spesifik. Untuk harga, konsumen mengungkapkan bahwa harga produk yang ditawarkan berada dalam rentang menengah keatas atau cukup mahal dibandingkan sate maranggi lainnya. Sementara dari segi kualitas produk, konsumen mengatakan kualitas produk sudah cukup baik, akan tetapi ada hal-hal yang sekiranya harus diperhatikan seperti: kemampuan pelayanan karyawan yang seringkali salah dalam mengantarkan pesanan serta kurangnya variasi makanan pelengkap. Untuk itu, perusahaan harus berupaya untuk mengevaluasi citra merek, harga, serta kualitas produk agar dapat meningkatkan pendapatan serta dapat menumbuhkan niat beli konsumen agar membeli secara berulang di Sate Maranggi SN4444.

Merek dengan citra yang baik akan mempengaruhi konsumen untuk membeli terhadap suatu produk. Perusahaan harus memiliki merk yang berbeda-beda dengan pesaing, begitu pun citra yang dipandang oleh konsumen. Penetapan harga suatu produk adalah suatu strategis yang harus dilakukan perusahaan dengan tepat karena harga akan menentukan penjualan produk sekaligus akan mempengaruhi pendapatan. Harga yang ditawarkan akan berkaitan dengan kualitas produk diberikan perusahaan terhadap konsumennya. Hal ini memperlihatkan bahwa citra merek, harga serta kualitas produk sangat berhubungan dan berkaitan erat untuk mendapatkan kepuasaan konsumen. Ketika konsumen mendapatkan kepuasaan yang sangat baik maka pembelian berulang akan dilakukan konsumen. Jika perusahaan tidak memahami citra merek, harga serta kualitas produk bagi keberlangsungan usahanya maka usaha yang dijalankan tersebut akan mengalami kemunduran dikemudian hari. Selain itu, pendapatan perusahaan akan mengalami penurunan akibat kurangnya strategi-strategi yang seharusnya dijalankan dengan baik dan maksimal.

\section{MATERI DAN METODE}

Pada hasil temuan yang telah didapat oleh Endang S dan Putri U (2018) tentang Pengaruh Bauran Pemasaran Terhadap Minat Beli Konsumen Pada Usaha Mikro Kecil Dan Menengah (UMKM) Produk Olahan Makanan Ringan mengemukakan bahwa secara simultan produk, harga, tempat, dan promosi memiliki pengaruh terhadap minat beli konsumen. Sedangkan secara parsial produk dan harga berpengaruh kepada minat beli konsumen, tetapi promosi dan tempat tidak memiliki pengaruh pada minat beli konsumen. Sedangkan hasil penelitian Junaedi dan Titiek TA (2015) dengan judul Pengaruh Citra Merek dan Atribut Produk Terhadap Keputusan Pembelian Smartphone Samsung Berbasis Android di Kota Bogor, mengemukakan bahwa citra merek dan atribut produk secara simultan berpengaruh kepada keputusan pembelian. Sedangkan citra merek dan atribut produk secara parsial memiliki pengaruh pada keputusan pembelian. Selain itu, Ruri PU dan Hendra S (2017) dengan judul Pengaruh Harga Dan Kualitas Produk Terhadap Minat Beli Sayuran Organik di Pasar Sambas Medan menunjukkan hasil positif dan signifikan pada hubungan antara harga dan kualitas produk terhadap minat beli secara simultan maupun parsial. Saepul dan Sudarijati (2015) meneliti 
dengan judul Analisis Brand Equity Sebagai Alat Bantu Perencanaan Strategi Pemasaran Pada Kendaraan Roda Empat Merek Toyota Avanza. Pada hasil penelitian tersebut diketahui brand awareness kendaraan roda empat jenis low $M p v$ kendaraan roda empat merek Avanza sebagai top of mind. Analisa brand association merek Toyota Avanza mempunyai sembilan atribut pembentuk brand image. Hasil analisa preceived quality merek Toyota Avanza secara keseluruhan menunjukan bahwa quality performance (persepsi konsumen terhadap kualitas produk) yang lebih rendah dibandingkan quality importance (harapan responden terhadap produk).

\section{Citra Merek (brand image)}

Menurut Tjiptono (2015:49), citra merek merupakan deskripsi asosiasi dan keyakinan konsumen terhadap merek tertentu. Citra merek (brand image) merupakan pengamatan dan kepercayaan yang di genggam konsumen seperti yang dicerminkan di asosiasi / di ingatan konsumen.

\section{Indikator Citra Merek}

Keller (2013:97) menyebutkan bahwa indikator citra merek adalah sebagai berikut :

1. Identitas Merek (brand identity)

2. Personalitas Merek (brand personality)

3. Asosiasi Merek (brand association)

4. Sikap dan Perilaku Merek (brand Attitude and behavior)

5. Manfaat dan Keunggulan Merek (brand benefit and competence)

\section{Harga}

Kotler dan Armstrong (2012:314) mendefinisikan harga sebagai sejumlah uang yang dibebankan untuk produk atau jasa, atau lebih jelasnya adalah jumlah dari keseluruhan nilai yang diberi oleh konsumen untuk mendapatkan sebuah manfaat dengan memiliki atau memakai suatu produk ataupun jasa.

\section{Indikator Harga}

Kotler dan Armstrong (2012: 318), mengemukakan ada 4 indikator harga yaitu : 1. Keterjangkauan Harga
2. Kesesuaian harga dengan kualitas produk

3. Kesesuaian harga dengan manfaat

4. Harga sesuai kemampuan atau daya saing harga

\section{Kualitas Produk}

Sangadji dan Sopiah (2013:99), menyebutkan bahwa kualitas adalah suatu keadaan dinamis yang berkaitan dengan produk, jasa, manusia, proses, dan lingkungan yang mencapai ataupun melebihi harapan.

\section{Indikator Kualitas Pruduk}

Menurut Tjiptono (2016:134), kualitas produk memiliki indikator sebagai berikut:

1. Kinerja (performance)

2. Fitur (features)

3. Keandalan (reliability)

4. Kesesuaian dengan spesifikasi (conformance to specification)

5. Daya tahan (durability)

6. Kemampuan pelayanan (serviceability)

7. Estetika (esthetics)

8. Persepsi kualitas (perceived quality),

\section{Minat Beli Ulang}

Thamrin dan Francis (2012:137), minat beli ulang ialah atensi membeli yang berdasarkan atas pengalaman dalam kepemilikan yang telah dilakukan sebelumnya. Tingginya minat membeli kembali memperlihatkan tingkat kepuasaan yang tinggi dari konsumen saat memutuskan untuk mengadopsi suatu produk. Besarnya minat membeli ulang ini akan memberikan dampak positif pada kesuksesan produk di pasaran.

\section{Indikator Minat Beli Ulang}

Menurut Hasan (2013:131) terdapat empat indikator minat beli ulang yaitu :

1. Minat transaksional

2. Minat referensial

3. Minat preferensial

4. Minat eksploratif

\section{Kerangka Pemikiran}

Adapun kerangka pemikiran dalam penelitian ini dapat dilihat pada gambar sebagai berikut ini: 
Pengaruh Citra Merek, Harga, dan Kualitas Produk Terhadap Minat Beli Ulang di Sate Maranggi SN4444 Tajur Kota Bogor

Rumusan Masalah

1. Bagaimana tanggapan konsumen terhadap citra merek, harga, kualitas produk dan minat beli ulang pada Sate Maranggi SN4444 Tajur Kota Bogor?

2. Bagaimana pengaruh secara simultan citra merek, harga, dan kualitas produk terhadap minat beli ulang pada Sate Maranggi SN4444 Tajur Kota Bogor?

3. Bagaimana pengaruh secara parsial citra merek, harga, dan kualitas produk terhadap minat beli ulang pada Sate Maranggi SN4444 Tajur Kota Bogor?

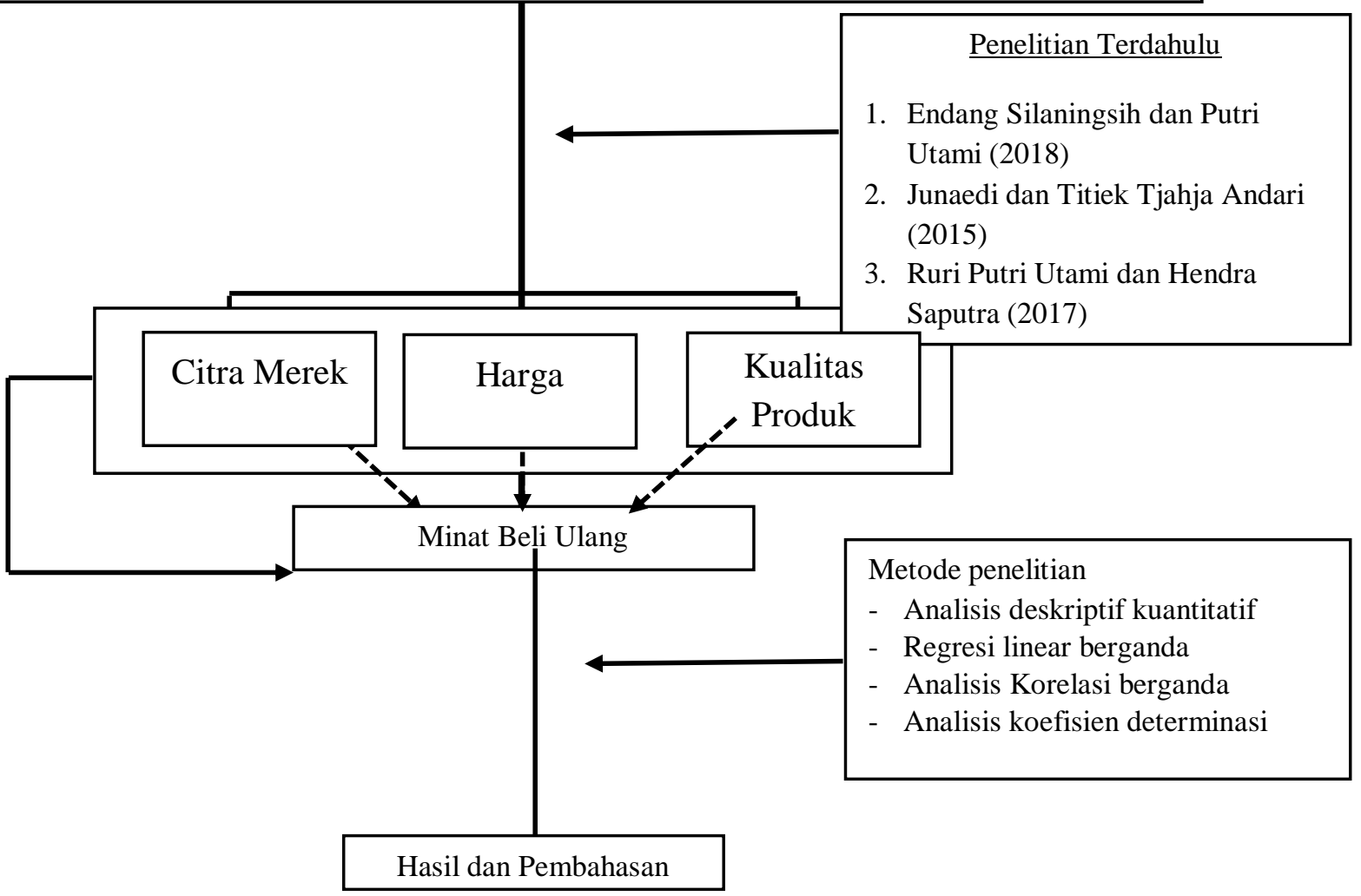

\section{Gambar 1 Kerangka Pemikiran}

\section{Metode Penelitian}

Objek pada penelitian ini yaitu citra merek, harga, kualitas produk serta minat beli ulang. Penelitian ini berlokasi di Jalan Raya Tajur, Bogor Timur, Kota Bogor.

Metode yang dipakai adalah deskriptif yang bersifat kuantitatif karena berkaitan dengan objek penelitian pada perusahaan dalam kurun waktu tertentu, mengumpulkan data serta informasi terkait dengan perusahaan yang kemudian disesuaikan dengan apa yang menjadi tujuan penelitian. Data bersumber dari data primer serta data sekunder. 
Tabel 3 Operasionalisasi Variabel

\begin{tabular}{|c|c|c|c|c|}
\hline Variabel & Konsep Variabel & Indikator & $\begin{array}{c}\text { Item } \\
\text { Pernyataan }\end{array}$ & Skala Ukur \\
\hline $\begin{array}{l}\text { Citra } \\
\text { Merek }\left(X_{1}\right)\end{array}$ & $\begin{array}{l}\text { Citra merek merupakan deskripsi } \\
\text { asosiasi dan keyakinan konsumen } \\
\text { terhadap merek tertentu. Citra merek } \\
\text { (brand image) merupakan pengamatan } \\
\text { dan kpercayaan yang di genggam } \\
\text { konsumen seperti yang dicerminkan di } \\
\text { asosiasi / di ingatan konsumen } \\
\text { Tjiptono, 2015:49) }\end{array}$ & $\begin{array}{l}\text { 1. Identitas Merek } \\
\text { 2. Personalitas Merek } \\
\text { 3. Asosiasi Merek } \\
\text { 4. Sikap dan Perilaku Merek } \\
\text { 5. Manfaat dan Keunggulan Merek }\end{array}$ & $\begin{array}{l}1-3 \\
4-5 \\
6-7 \\
8-9 \\
10-11\end{array}$ & Ordinal \\
\hline Harga $\left(X_{2}\right)$ & $\begin{array}{l}\text { Harga sebagai sejumlah uang yang } \\
\text { dibebankan untuk produk atau jasa, atau } \\
\text { lebih jelasnya adalah jumlah dari } \\
\text { keseluruhan nilai yang diberi oleh } \\
\text { konsumen untuk mendapatkan sebuah } \\
\text { manfaat dengan memiliki atau memakai } \\
\text { suatu produk ataupun jasa (Kotler dan } \\
\text { Armstrong 2012:314) }\end{array}$ & $\begin{array}{l}\text { 1. Keterjangkauan harga } \\
\text { 2. Kesesuaian harga dengan kualitas } \\
\text { produk } \\
\text { 3. Kesesuaian harga dengan manfaat } \\
\text { 4. Harga sesuai kemampuan atau } \\
\text { daya saing harga }\end{array}$ & $\begin{array}{l}1-2 \\
3-4 \\
\\
5-6 \\
7-8\end{array}$ & Ordinal \\
\hline $\begin{array}{l}\text { Kualitas } \\
\text { Produk } \\
\left(\mathrm{X}_{3}\right)\end{array}$ & $\begin{array}{l}\text { Kualitas adalah suatu keadaan dinamis } \\
\text { yang berkaitan dengan produk, jasa, } \\
\text { manusia, proses, dan lingkungan yang } \\
\text { memenuhi ataupun melebihi harapan ( } \\
\text { Sangadji dan Sopiah, } 2013: 99 \text { ) }\end{array}$ & $\begin{array}{l}\text { 1. Kinerja } \\
\text { 2. Fitur } \\
\text { 3. Keandalan } \\
\text { 4. Kesesuaian dengan spesifikasi } \\
\text { 5. Daya tahan } \\
\text { 6. Kemampuan pelayanan } \\
\text { 7. Estetika } \\
\text { 8. Persepsi kualitas }\end{array}$ & $\begin{array}{c}1-2 \\
3-4 \\
5-6 \\
7-8 \\
9-10 \\
11-12 \\
13-14 \\
15-16\end{array}$ & Ordinal \\
\hline $\begin{array}{l}\text { Minat Beli } \\
\text { Ulang (Y) }\end{array}$ & $\begin{array}{l}\text { Minat beli ulang ialah intensi membeli } \\
\text { yang berdasarkan atas pengalaman } \\
\text { dalam pembelian yang telah sebelumnya } \\
\text { dilakukan. Tingginya minat membeli } \\
\text { kembali memperlihatkan tingkat } \\
\text { kepuasan yang tinggi dari konsumen } \\
\text { saat memutuskan untuk mengadopsi } \\
\text { suatu produk. Besarnya minat membeli } \\
\text { ulang ini akan memberikan dampak } \\
\text { positif pada kesuksesan produk di } \\
\text { pasaran. (Thamrin dan Francis, } \\
\text { 2012:137) }\end{array}$ & $\begin{array}{l}\text { 1. Minat transaksional } \\
\text { 2. Minat referensial } \\
\text { 3. Minat preferensial } \\
\text { 4. Minat eksploratif }\end{array}$ & $\begin{array}{l}1-2 \\
3-4 \\
5-6 \\
7-8\end{array}$ & Ordinal \\
\hline
\end{tabular}

\section{Sampel Penelitian}

Unit penelitian dipilih dengan sengaja (purposive) yang dilakukan di Sate Maranggi SN4444 Tajur, Kota Bogor. Sedangkan populasinya adalah konsumen Sate Maranggi SN444 di Tajur Kota Bogor. Konsumen Sate Maranggi SN444 di Tajur Kota Bogor tidak diketahui dengan pasti jumlahnya. Sehingga teknik penetapan sampel yang digunakan adalah teknik atau pendekatan non probability sampling. Teknik non probability sampling pada penelitian ini yaitu dengan metode incidental sampling. Untuk sampel ditentukan berdasarkan rumus Soewadji (2012: 135) adalah sebagai berikut:

$$
\begin{aligned}
N=\frac{Z^{2}}{4(m o e)^{2}} & N=\frac{(1,96)^{2}}{4(0,1)^{2}} \\
& =96,04 \text { dibulatkan } 100
\end{aligned}
$$


Keterangan :

$\mathrm{N}=$ jumlah sampel

$\mathrm{Z} \quad=$ tingkat distribusi normal pada

taraf signifikasi 5\% $(1,96)$

Moe $\quad=$ margin of error max, adalah

tingkat kesalahan maksimal pengambilan

sampel

\section{Metode Pengumpulan Data}

Menurut Sugiyono (2014:225), metode pengumpulan data sebagai berikut :

1. Studi Lapangan (field research)

a. Observasi

b. Wawancara

c. Kuesioner

2. Studi Pustaka ( library research)

\section{Pengujian Instrumen}

Uji validitas dilakukan untuk melihat seberapa jauh alat pengukur mampu mentaksir sesuatu yang ingin diukur. Sebelum instrumen digunakan untuk mendapatkan data, lebih baik diuji validitasnya kepada konsumen dengan memakai rumus teknik korelasi product moment.

Menurut Sugiyono (2014:203), instrumen yang reliabel yaitu instrumen yang jika digunakan berkali-kali untuk mentaksir target yang sama akan memberikan hasil data yang sama atau apabila tanggapan seseorang terhadap instrumen adalah presisten atau tetap dari masa ke masa. Untuk menguji hipotesis, hasil estimasi akan ditaksir dengan metode Ordinary Least Square (OLS), yaitu:

1. Uji Normalitas

2. Uji Multikolinieritas

3. Uji Heterokedastisitas

\section{Regresi Linear Berganda}

Menurut Sugiyono (2014:277), analisis regresi linear berganda berguna untuk memprediksi bagaimana kondisi (naik turunnya) variabel terikat, bila dua maupun lebih variabel bebas sebagai faktor prediator dimanipulasi (dinaik turunkan nilainya). Menurut Sugiyono (2014:277) sebagai berikut persamaan regresi linear berganda:

$$
\mathbf{Y}=\alpha+\boldsymbol{\beta}_{1} \mathbf{X}_{1}+\boldsymbol{\beta}_{2} \mathbf{X}_{2}+\boldsymbol{\beta}_{3} \mathbf{X}_{3}+\varepsilon
$$

Analisis Korelasi Berganda

Untuk mengetahui bagaimana korelasi antara citra merek, harga, serta kualitas produk dengan minat beli ulang maka digunakan rumus sebagai berikut:

$$
r X i Y=\frac{n \Sigma X i Y-(\Sigma X i)(\Sigma Y)}{\sqrt{\left\{n \Sigma X i^{2}-\left(\Sigma X i^{2}\right)\right\}\left\{n \Sigma Y^{2}-(\Sigma Y)\right\}}}
$$

Dari rumus analisis korelasi tersebut, maka akan diperoleh nilai $r$ yang besarnya antara -1, 0 sampai 1. Notasi ini menggunakan korelasi atau hubungan antara variabelvariabel yang diuji dalam penelitian.

\section{Analisis Koefisien Determinasi}

Atmaja dkk (2014:122), menyatakan bahwa koefisien determinasi $\left(\mathrm{R}^{2}\right)$ dipergunakan untuk mengamati seberapa jauh keseluruhan variabel independen dapat menjelaskan variabel dependen koefisien determinasi dapat diketahui dengan rumus:

$$
K d=r^{2} \times 100 \%
$$

\section{Pengujian Hipotesis}

Uji statistik F apakah variabel independen yang dimaksud dalam model memiliki pengaruh secara bersama-sama (simultan) terhadap variabel dependen. Dengan level signifikansi yang ditetapkan adalah 5\% atau derajat kebebasan (degreeof fredom) $95 \%$.

Uji statistik $\mathrm{t}$ dipergunakan untuk memeriksa apakah variabel bebas yang dipakai ke dalam model memiliki pengaruh secara individual terhadap variabel terikat dengan menggunakan tingkat signifikansi 5\%.

\section{HASIL DAN PEMBAHASAN}

\section{Karakteristik Konsumen}

Karakteristik konsumen yang sudah pernah mencoba produk di Sate Maranggi SN4444 Tajur Kota Bogor tahun 2019, dengan uraian sebagai berikut : 
Tabel 4 Rekapitulasi Karakteristik Konsumen

\begin{tabular}{clccc}
\hline No & Karakteristik & Ciri-ciri Konsumen & $\begin{array}{c}\text { Jumlah } \\
\text { Konsumen } \\
\text { (Orang) }\end{array}$ & $\begin{array}{c}\text { Persentase } \\
(\%)\end{array}$ \\
\hline 1 & Jenis Kelamin & Laki-laki & 53 & 53 \\
2 & Usia & 29-34 tahun & 43 & 43 \\
3 & Pekerjaan & PNS/Pegawai BUMN & 39 & 39 \\
4 & Tingkat Pendapatan & $\geq$ Rp5.000.000 & 36 & 36 \\
5 & Frekuensi Pembelian & $>3$ kali & 36 & 36 \\
\hline
\end{tabular}

Sumber: Data diolah, 2019

Tabel 4 memperlihatkan bahwa sebagian besar konsumen adalah laki-laki berusia 29-34 tahun, pekerjaan sebagai PNS/ Pegawai BUMN, tingkat pendapatan perbulan berkisar $\geq$ Rp5.000.000 perbulan, dan frekuensi pembelian produk di Sate Maranggi SN4444 sebanyak >3 kali. Pada Tabel 5 berikut ini merupakan tabel rekapitulasi tanggapan konsumen terhadap citra merek, harga, kualitas produk, serta minat beli ulang di Sate Maranggi SN4444 Tajur Kota Bogor.

\section{Tabel 5 Rekapitulasi Tanggapan Konsumen}

\begin{tabular}{|c|c|c|c|c|}
\hline No & Uraian & Penilaian & Keterangan & Interpretasi \\
\hline 1 & Citra Merek & 4,47 & Sangat Baik & $\begin{array}{l}\text { Citra merek pada Sate Maranggi SN4444 dikatakan sangat baik } \\
\text { karena memiliki ciri khas yang mudah diingat oleh konsumen, } \\
\text { sepeti: slogan, warna kuning terang, ataupun pembakaran sate } \\
\text { langsung di gerobak. }\end{array}$ \\
\hline 2 & Harga & 4,35 & Sangat Sesuai & $\begin{array}{l}\text { Harga pada Sate Maranggi SN4444 dikatakan sangat sesuai } \\
\text { karena jumlah uang yang dikeluarkan sesuai dengan manfaat dan } \\
\text { kualitas produk yang diberikan. }\end{array}$ \\
\hline 3 & Kualitas Produk & 4,48 & Sangat Baik & $\begin{array}{l}\text { Kualitas produk Sate Maranggi SN4444 dikatakan sangat baik } \\
\text { karena produk yang dijual menggunakan bahan utama daging } \\
\text { import dan bahan bahan lainnya yang fresh dan aman sehinga } \\
\text { produk yang ditawarkan kepada konsumen sudah terjamin } \\
\text { kualitasnya. Selain itu, salah satu keterjaminan dan keamanan } \\
\text { produk adalah kehalalan produk sehingga konsumen merasa } \\
\text { aman melakukan pembelian di Sate Maranggi SN4444 }\end{array}$ \\
\hline 4 & $\begin{array}{l}\text { Minat } \\
\text { Ulang }\end{array}$ & 4,24 & Sangat Tinggi & $\begin{array}{l}\text { Minat membeli kembali pada Sate Maranggi SN4444 dikatakan } \\
\text { sangat tinggi karena konsumen ingin melakukan pembelian } \\
\text { kembali dan merekomendasikan kepada teman ataupun kerabat } \\
\text { dekat serta ingin mengetahui informasi lebih banyak tentang Sate } \\
\text { Maranggi SN4444. Konsumen menyukai produk yang } \\
\text { ditawarkan sehingga melakukan pembelian lebih dari } 3 \text { kali } \\
\text { pembelian. }\end{array}$ \\
\hline
\end{tabular}

Berdasarkan Tabel 5 rekapitulasi tanggapan konsumen terhadap variabel dalam penelitian ini, maka dapat dilihat nilai tertinggi 4,48 yaitu kualitas produk dan nilai terendah 4,24 yaitu minat beli ulang.

\section{Hasil Regresi Linear Berganda}

Berdasarkan perhitungan dengan menggunakan alat bantu SPSS, maka dapat diketahui persamaan sebagai berikut:

$$
Y=0,602+0,203 X_{1}+0,256 X_{2}+0,203 X_{3}+\varepsilon
$$


Persamaan regresi tersebut diketahui bahwa citra merek $\left(\mathrm{X}_{1}\right)$, harga $\left(\mathrm{X}_{2}\right)$ dan kualitas produk $\left(\mathrm{X}_{3}\right)$ bernilai positif yang berarti hubungan antar variabel memiliki hubungan searah. Hubungan searah disini berarti jika semakin baik variabel bebas maka akan semakin baik pula variabel terikat, begitu pun sebaliknya, jika semakin buruk variabel bebas makan akan semakin buruk pula variabel terikat. Sehingga menunjukkan semakin tinggi nilai dari tiga variabel tersebut, maka minat beli ulang pada akan semakin tinggi.

\section{Analisis Korelasi Berganda}

berikut:

Tabel 6 Hasil Analisis Koefisien Korelasi dan Koefisien Determinasi Model Summary ${ }^{b}$

\begin{tabular}{llrrr}
\hline Model & R & R Square & $\begin{array}{c}\text { Adjusted R } \\
\text { Square }\end{array}$ & $\begin{array}{c}\text { Std. Error of the } \\
\text { Estimate }\end{array}$ \\
\hline 1 & $.710^{\mathrm{a}}$ & .504 & .488 & 1.790 \\
\hline
\end{tabular}

Sumber: Data diolah, 2019

Dari perhitungan tersebut dapat diketahui bahwasanya nilai $\mathrm{R}$ sebesar 0,710 yang menunjukkan korelasi atau hubungan dari variabel bebas yaitu, citra merek $\left(\mathrm{X}_{1}\right)$, harga $\left(\mathrm{X}_{2}\right)$, dan kualitas produk $\left(\mathrm{X}_{3}\right)$ dengan variabel minat beli ulang (Y) mempunyai korelasi yang termasuk kuat $(0,60-0,799)$, artinya adalah ketika nilai variabel $\mathrm{X}$ mengalami peningkatan akan diikuti oleh peningkatan nilai variabel $Y$ atau semakin meningkatnya niali citra merek, harga, serta kuallitas produk maka akan semakin meningkat pula minat beli ulang. Nilai R sebesar 0,710 dan berada pada rentang 0,60-0,7999 maka termasuk dalam kategori kuat. Hal ini menunjukkan bahwa semakin baik citra merek, harga serta kualitas produk lantas akan berdampak positif pada minat beli ulang.

\section{Hasil Koefisien Determinasi}

Koefisien determinasi bertujuan untuk mendapatkan besaran persentase kontribusi pengaruh variabel bebas secara bersama terhadap variabel terikat dengan cara melihat nilai $\mathrm{R}$ square. Berdasarkan Tabel 6 tersebut juga dapat diketahui bahwa besarnya $R$ Square sebesar 0,504 atau 50,4\%. Maka dapat diketahui bahwa besaran persentase kontribusi pengaruh variabel citra merek $\left(\mathrm{X}_{1}\right)$, harga $\left(\mathrm{X}_{2}\right)$, dan kualitas produk $\left(\mathrm{X}_{3}\right)$ terhadap minat beli ulang (Y) sebesar 50,4\%. Sedangkan sisanya $49,6 \%$ terpengaruh oleh faktor selain dari variabel yang digunakan pada model penelitian ini. Pengaruh faktor-faktor selain yang tidak dipakai di penelitian ini seperti faktor kultur, psikologis, pribadi, dan sosial. Hal ini sesuai dengan teori yang disampaikan oleh Kotler dan Amrstrong (2011:135-150) tentang faktor faktor yang mempengaruhi minat seseorang untuk melakukan pembelian ulang.

Uji-F

Tabel 7 Pengujian Regresi Secara Simultan

ANOVA ${ }^{a}$

\begin{tabular}{lcrrrr}
\hline Model & Sum of Squares & Df & Mean Square & \multicolumn{1}{c}{ F } & Sig. \\
\hline 1 Regression & 312.106 & 3 & 104.035 & 32.455 & $.000^{\mathrm{b}}$ \\
Residual & 307.734 & 96 & 3.206 & & \\
Total & 619.840 & 99 & & & \\
\hline
\end{tabular}

Sumber: Data diolah, 2019

Dari nilai $F$ pada tabel tersebut, yaitu $F_{\text {hitung }}$ sebesar 32.455 dan nilai $F_{\text {tabel }}$ untuk $\alpha=$ 0,05 dengan derajat kebebasan $\mathrm{V} 1=4-1=3$ dan $\mathrm{V} 2=100-3-1=96$ adalah sebesar 2,70 ; maka

dapat dilihat $F_{\text {hitung }}$ lebih besar dari $F_{\text {tabel }}$ (32.455> 2,70). Maka hasilnya adalah Ho ditolak dan $\mathrm{Ha}$ diterima, artinya dengan kepercayaan $95 \%$ variabel $\mathrm{X}$ yaitu citra merek 
$\left(\mathrm{X}_{1}\right)$, harga $\left(\mathrm{X}_{2}\right)$, dan kualitas produk $\left(\mathrm{X}_{3}\right)$ berpengaruh positif dan signifikan secara bersamaan terhadap minat beli ulang (Y). Hasil didukung oleh penelitian yang dilakukan oleh Silvia Nurfitriana dan Francy Iriani (2015) bahwa pengaruh simultan citra merek, harga, dan kualitas produk terhadap minat beli ulang positif dan signifikan.
Uji-t

Uji $\mathrm{t}$ dilakukan dengan membandingkan $\mathrm{t}$ hitung dan $\mathrm{t}$ tabel. Jika nilai $t_{\text {hitung }}$ lebih tinggi dari $t$ tabel $\left(t_{\text {hitung }}>t_{\text {tabel }}\right)$ maka menunjukkan bahwa variabel independen mempunyai pengaruh secara parsial kepada variabel dependen. Secara lebih jelas hasilnya bisa dilihat pada Tabel 8 berikut ini:

Tabel 8 Pengujian Regresi Secara Parsial Coefficients $^{a}$

\begin{tabular}{llccccc}
\hline \multirow{2}{*}{ Model } & \multicolumn{2}{c}{$\begin{array}{c}\text { Unstandardized } \\
\text { Coefficients }\end{array}$} & $\begin{array}{c}\text { Standardized } \\
\text { Coefficients }\end{array}$ & & T & Sig. \\
\cline { 2 - 5 } & (Constant) & B & Std. Error & Beta & & \\
\hline \multirow{2}{*}{1} & .602 & 3.469 & & .173 & .863 \\
& Citra Merek $\left(\mathrm{X}_{1}\right)$ & .203 & .079 & .232 & 2.581 & .011 \\
& Harga $\left(\mathrm{X}_{2}\right)$ & .256 & .083 & .265 & 3.060 & .003 \\
& Kualitas Produk $\left(\mathrm{X}_{3}\right)$ & .203 & .053 & .359 & 3.816 & .000 \\
\hline
\end{tabular}

Sumber: Data diolah, 2019

Tabel tersebut menyajikan hasil perhitungan, dapat terlihat nilai thitung dan nilai signifikan dari setiap variabel independen. Sedangkan nilai $t_{\text {tabel }}$ untuk $\alpha=0,05$ dengan derajat kebebasan 100-3-1 = 1,666. Dengan demikian maka diperoleh hasil sebagai berikut: Citra merek $\left(\mathrm{X}_{1}\right)$ dengan nilai $t_{\text {hitung }}$ sebesar 2,581 lebih besar dari nilai $t_{\text {tabel }}(2,581>$ 1,666). Lantas Ho ditolak dan Ha diterima, artinya hubungan citra merek terhadap minat beli ulang positif dan signifikan. Hasil ini dikuatkan oleh penelitian yang dilakukan oleh Afif GR dan Suryono BS (2017) bahwa citra merek mempunyai pengaruh positif juga signifikan kepada minat beli ulang. Harga $\left(\mathrm{X}_{2}\right)$ dengan nilai thitung sebesar 3,060 lebih besar dari nilai $t_{\text {tabel }}(3,060>1,666)$. Dengan demikian Ha diterima dan Ho ditolak, artinya pengaruh harga terhadap minat beli ulang positif serta signifikan. Hal ini didukung dengan penelitian yang dilakukan oleh Hermanto dan Cahyadi (2015) bahwa harga mempunyai pengaruh positif serta signifikan kepada minat beli ulang. Kualitas Produk $\left(\mathrm{X}_{3}\right)$ dengan nilai thitung sebesar 3,816 lebih besar dari nilai tabel $(3,816>1,666)$. Lantas Ho ditolak dan $\mathrm{Ha}$ diterima, artinya pengaruh kualitas produk kepada minat beli ulang positif dan signifikan. Pernyataan ini dikuatkan penelitian Faradiba dan Rahayu (2013) bahwasanya kualitas produk mempunya pengaruh yang positif juga signifikan pada minat beli ulang.

\section{Kesimpulan}

Kesimpulan penelitian adalah sebagai berikut.

1. Tanggapan konsumen terhadap citra merek, harga, kualitas produk serta minat beli ulang di Sate Maranggi SN4444 Tajur Kota Bogor

a. Tanggapan konsumen terhadap citra merek dengan kategori sangat baik. Penilaian tertinggi pada pernyataan Sate Maranggi SN4444 menawarkan produk sesuai dengan keinginan. Sedangkan tanggapan konsumen terhadap citra merek yang menunjukkan penilaian terendah yaitu dengan pernyataan saya mengetahui Sate Maranggi SN4444 merupakan donatur acara sosial yang diselenggarakan di lingkungannya.

b. Tanggapan konsumen terhadap harga dengan kategori sangat sesuai. Penilaian tertinggi pernyataan harga sesuai dengan manfat produk yang diberikan. Sedangkan tanggapan konsumen terhadap harga yang 
menunjukkan penilaian terendah yaitu dengan pernyataan harga produk yang ditawarkan oleh Sate Maranggi SN4444 terjangkau oleh konsumen.

c. Tanggapan konsumen tpada kualitas produk dengan kategori sangat baik. Penilaian tertinggi pernyataan proses pembakaran di Sate Maranggi SN4444 memiliki daya tarik tersendiri yang berbeda dengan sate maranggi lainnya. Sedangkan tanggapan konsumen yang menunjukkan penilaian terendah yaitu dengan pernyataan Sate Maranggi SN4444 memiliki tampilan produk yang menarik.

d. Tanggapan konsumen minat beli ulang memberikan nilai yang sangat tinggi. Penilaian tertinggi pernyataan Sate Maranggi SN4444 menawarkan produk sesuai dengan keinginan. Sedangkan tanggapan konsumen yang menunjukkan penilaian terendah yaitu dengan pernyataan saya lebih memilih makan di Sate Maranggi SN4444 daripada mencoba sate maranggi yang lainnya.

2. Citra merek, harga, dan kualitas produk berpengaruh secara bersamaan kepada minat beli ulang pada Sate Maranggi SN4444 Tajur Kota Bogor dengan positif dan signifikan.

3. Pengaruh secara parsial variabel tidak terikat terhadap variabel terikat adalah sebagai berikut:

a. Citra merek mempunyai pengaruh positif serta signifikan pada minat beli ulang di Sate Maranggi SN4444 Tajur Kota Bogor

b. Harga mempunyai pengaruh positif serta signifikan pada minat beli ulang di Sate Maranggi SN4444 Tajur Kota Bogor,

c. Kualitas produk mempunyai pengaruh positif juga signifikan pada minat beli ulang di Sate Maranggi SN4444 Tajur Kota Bogor.

\section{Saran}

1. Citra merek merupakan variabel yang memiliki pengaruh paling kecil kepada minat beli ulang di Sate Maranggi SN4444. Oleh sebab itu, sebaiknya perusahaan menambah ciri khas dari Sate Maranggi tersebut agar lebih dikenal dan mendapat perhatian pertama ketika konsumen ingin melakukan pembelian kembali

2. Dalam menetapkan harga, Sate Maranggi SN4444 sebaiknya melakukannya dengan cermat dan hati-hati, karena harga merupakan variabel yang paling kuat mempengaruhi minat beli ulang di Sate Maranggi SN4444. Jika perusahaan salah dalam mengambil kebijakan penetapan harga. Hal tersebut akan mengakibatkan penurunan jumlah konsumen yang akan melakukan pembelian.

3. Kualitas produk merupakan variabel yang memiliki pengaruh paling kecil dibandingkan citra merek pada minat beli ulang pada Sate Maranggi SN4444. Oleh sebab itu, sebaiknya perusahaan meningkatkan kualitas produk dari segala aspek yang masih belum maksimal. Jika perusahaan masih kurang baik dalam memberikan kualitas produk maka perusahaan akan kalah dalam persaingan bisnis kuliner lainnya yang memberikan kualitas lebih baik. Kualitas produk dapat ditingkatkan dengan cara menjaga kualitas bahan-bahan yang digunakan ataupun memperbaiki pelayanan terhadap konsumen.

4. Bagi peneliti selanjutnya sebaiknya mengembangkan variabel-variabel yang tidak diteliti yang berhubungan dengan minat beli ulang, sebab tidak menutup kemungkinan bahwa dengan penelitian yang mencakup lebih banyak variabel akan memberikan kesimpulan yang lebih baik. Pengaruh faktor-faktor yang tidak ada dalam penelitian ini seperti faktor kultur, psikologis, pribadi, dan sosial. 


\section{UCAPAN TERIMAKASIH}

Terimakasih kepada semua pihak yang sudah berkontribusi dalam penelitian ini sehingga dapat terlaksana dengan baik.

\section{DAFTAR PUSTAKA}

Afif Ghaffar Ramadhan dan Suryono Budi Santosa. 2017. Analisis Pengaruh Kualitas Produk, Kualitas Pelayanan dan Citra Merek Terhadap Minat Beli Ulang Pada Sepatu Nike Runing di Semarang Melalui Kepuasan Pelanggan Sebagai Variabel Intervening. Diponegoro Journal Of Management Vol. 6 No. 1 Hal 1-12.

Alma, Buchari. 2011. Manajemen Pemasaran dan Pemasaran Jasa. Cetakan ke-9. Alfabeta. Bandung

Dinas Parwisata dan Kebudayaan Provinsi Jawa Barat. 2016. Jumlah Restoran/Rumah Makan Menurut Kota/Kabupaten di Provinsi Jawa Barat

Endang Silaningsih dan Putri Utami. 2018. Pengaruh Bauran Pemasaran Terhadap Minat Beli Konsumen pada Usaha Mikro Kecil dan Menengah (UMKM) Produk Olahan Maknan Ringan. Jurnal Sosial Humaniora, Hal 144-158.

Faradiba dan Astuti, Sri Rahayu Tri. 2013. Analisis Pengaruh Produk, Harga, Lokasi dan Kualitas Pelayanan Terhadap Minat Beli Ulang Konsumen. Diponegoro Journal Of Management Vol. 2 No. 3 Hal 1-11.

Ghozali, Imam. 2013. Aplikasi Analysis Multivairiate dengan Programe SPSS. Penerbit Universitas Diponegoro. Semarang.

Hasan, Ali. 2013. Marketing dan Kasus kasus pilihan. Center For Academic Publishing Service. Yogyakarta

Junaedi dan Titiek Tjahja Andari. 2015. Pengaruh Citra Merek Dan Atribut
Produk Terhadap Keputusan Pembelian Smartphone Samsung Berbasis Android di Kota Bogor. Jurnal Visionida, Volume 1 Nomor 2, Hal 31-44.

Keller, Kevin L. 2013. Strategic Brand Management: Building Measuring, and Managing Brand Equity. Fourth Edition Harlow. Pearson Education Inc. English

Kenly Hermanto dan Irvan Cahyadi. 2015. Pengaruh Kualitas Produk dan Harga Terhadap Minat Beli Ulang Fast Food Ayam Goreng Tepung di Kalangan Mahasiswa Universitas Keristen Petra Surabaya. Jurnal Hospitality dan Manajemen Jasa Vol. 3 No. 2 Hal 561573.

Kotler, Philip dan Gary Armstrong. 2012. Prinsip Prinsip Pemasaran. Edisi 12. Jilid 1. Erlangga. Jakarta

Ruri Putri Utami dan Hendra Saputra. 2017. Pengaruh Harga dan Kualitas Produk Terhadap Minat Beli Sayuran Organik di Pasar Sambas Medan. Jurnal Niagawan Vol. 6 No. 2 Hal 127-137.

Saepul Rohman Hamdani dan Sudarijati. 2015. Analysis Brand Equity Sebagai Alat Bantu Perencanaan Strategik Pemasaran Pada Kendaraan Roda Empat Merek Toyota Avanza. Jurnal Visionida Vol. 1 No. 2 Hal. 1-14.

Sangadji, Etta Mamang dan Sopiah. 2013. Perilaku Konsumen Pendekatan Praktis disertai Himpunan Jurnal Penelitian. Andi. Yogyakarta

Sugiyono. 2014. Metode Penelitian Kuantitatif, Kualitatif, dan R\&D. Alfabeta. Bandung

Thamrin Abdullah dan Francis Tantri. 2012. Manajemen Pemasaran. Rajawali Pers. Jakarta

Tjiptono, Fandy. 2015. Strategi Pemasaran. Edisi 4. Andi. Yogyakarta 